\title{
TINGKAT PENGETAHUAN PETUGAS TENTANG STANDAR PELAYANAN MINIMAL DI INSTALASI GAWAT DARURAT DAN PENUNJANG PELAYANAN KEGAWATDARURATAN RUMAH SAKIT UMUM DAERAH KABUPATEN KLUNGKUNG TAHUN 2018
}

\author{
Made Riastuti Sumandari*, Rina Listyowati \\ Program Studi Kesehatan Masyarakat Fakultas Kedokteran Universitas Udayana \\ *E-mail: riastuti.suman@gmail.com
}

\begin{abstract}
ABSTRAK
Rumah Sakit Umum Daerah Kabupaten Klungkung sebagai rumah sakit yang sudah menerapkan Pengelolaan Keuangan Badan Layanan Umum terus meningkatkan dan mengembangkan mutu pelayanan, terutama mutu pelayanan kegawatdaruratan. Tujuan penelitian ini untuk mengetahui gambaran tingkat pengetahuan petugas di Instalasi Gawat Darurat dan Penunjang Pelayanan Kegawatdaruratan Rumah Sakit Umum Daerah Kabupaten Klungkung tentang Standar Pelayanan Minimal. Penelitian ini merupakan penelitian deskriptif kuantitatif, dengan rancangan cross-sectional. Populasi dalam penelitian ini adalah seluruh petugas yang bekerja di Instalasi Gawat Darurat dan penunjang pelayanan kegawatdaruratan. Jumlah sampel pada penelitian ini 94 petugas dengan teknik pengumpulan sampel yaitu total sampling. Teknik pengumpulan data pada penelitian ini yaitu dengan menyebarkan kuesioner dan analisis data yang digunakan yaitu analisis univariat. Hasil penelitian ini adalah mayoritas petugas memiliki pengetahuan baik mengenai SPM yaitu sebesar 86,17\% sedangkan 13,83\% memiliki pengetahuan kurang baik. Dilihat dari tingkat pengetahuan berdasarkan karakteristik, pengetahuan baik sebagian besar pada umur umur $\geq 30$ (88,14\%), jenis kelamin perempuan $(96,23 \%)$, pendidikan DIII (87,93\%) dan masa kerja $>10$ tahun (88,46\%). Saran yang bisa diberikan kepada Rumah Sakit Umum Daerah Kabupaten Klungkung, sebaiknya rumah sakit memberikan sosialisasi kepada seluruh petugas mengenai SPM dengan rutin dan terjadwal sehingga petugas mendapatkan informasi mengenai SPM merata.
\end{abstract}

Kata Kunci: Tingkat Pengetahuan, Standar Pelayanan Minimal

\begin{abstract}
Klungkung Regency Regional General Hospital as a hospital that has implemented Financial Management Public Service Agency continues to improve and develop the quality of services, especially the quality of emergency services. The purpose of this study was to determine the level of knowledge of officers in the Emergency Installation and Supporting Emergency Services of the Klungkung Regency General Hospital on Minimum Service Standards. This research is a quantitative descriptive study, with a cross-sectional design. The population in this study were all officers who worked in the Emergency Installation and supporting emergency services. The number of samples in this study were 94 officers with total sample collection techniques. Data collection techniques in this study are by distributing questionnaires and data analysis used is univariate analysis. The results of this study were that the majority of officers had good knowledge of MSS, amounting to $86.17 \%$ while $13.83 \%$ had poor knowledge. Judging from the level of knowledge based on characteristics, good knowledge is mostly at the age of $\geq 30$ (88.14\%), female gender (96.23\%), DIII education (87.93\%) and years of service> 10 years (88, 46\%). Suggestions that can be given to the Klungkung Regency Regional General Hospital, the hospital should provide information to all officers on MSS routinely and on a regular basis so that officials get information about SPM evenly.
\end{abstract}

Keywords: Knowledge Level, Minimum Service Standards.

\section{PENDAHULUAN}

Rumah sakit merupakan tempat penyedia layanan kesehatan bagi masyarakat. Rumah sakit merupakan salah satu sektor yang berperan penting dalam pembangunan nasional. Undang Undang No. 44 Tahun 2009 tentang rumah sakit menjelaskan bahwa rumah sakit 
adalah institusi kesehatan yang menyelenggarakan pelayanan kesehatan perorangan secara paripurna dengan menyediakan pelayanan rawat inap, rawat jalan, serta gawat darurat.

Kabupaten Klungkung memiliki satu Rumah Sakit Umum yaitu RSUD Kabupaten Klungkung yang terletak di jalan Flamboyan No. 40, Semarapura. Rumah Sakit Umum Daerah Kabupaten Klungkung merupakan rumah sakit kelas B milik Pemerintah Kabupaten Klungkung yang berdiri sejak tahun 1963 dan baru ditetapkan sebagai Rumah Sakit Umum Daerah sejak tahun 1986. Sejak tanggal 1 Januari 2012 RSUD Kabupaten Klungkung menerapkan Pola Pengelolaan Keuangan Badan Layanan Umum Daerah (PPKBLUD) yang didasari oleh Keputusan Bupati Klungkung Nomor : 253 Tahun 2011 tanggal 23 Desember 2011 tentang Penetapan RSUD Kabupaten Klungkung untuk menerapkan Pola Pengelolaan Keuangan Badan Layanan Umum Daerah. RSUD Kabupaten Klungkung sangat serius dalam mengembangkan pelayanan kegawatdaruratan hal tersebut terlihat dari Visi RSUD Kabupaten Klungkung yaitu rumah sakit pilihan terbaik dan unggul dalam pelayanan kedaruratan di Bali Timur.

Rumah Sakit Umum Daerah Kabupaten Klungkung yang menerapkan sistem keuangan Badan Layanan Umum Daerah (BLUD), maka perlu menerapkan Standar Pelayanan Minimal untuk memberikan gambaran atau tolok ukur terhadap layanan minimum yang diberikan kepada masyarakat, seperti yang dijelaskan dalam Peraturan
Pemerintah Nomor 23 Tahun 2005 tentang pengelolaan keuangan badan layanan umum. Penerapan SPM di RSUD Kabupaten Klungkung mengacu pada Peraturan Bupati Klungkung Nomor 7 Tahun 2012 tentang Standar Pelayanan Minimal BLUD RSUD Kabupaten Klungkung. Standar pelayanan minimal (SPM) adalah indikator tentang jenis dan mutu pelayanan dasar yang merupakan hal wajib setiap daerah yang berhak dipereroleh oleh setiap warga secara minimum serta merupakan spesifikasi teknis tentang tolok ukur pelayanan minimum yang diberikan kepada masyarakat. Dengan adanyan SPM RSUD Kabupaten Klungkung, dapat melihat kegiatan yang dilakukan, indikator serta standar kinerjanya, sehingga hal ini akan mempermudah untuk melihat sejauh mana pelayanan minimal yang telah dilakukan serta memudahkan dalam menilai kinerja RSUD Kabupaten Klungkung. Beberapa hal yang mempengaruhi tidak tercapainya standar nasional dalam SPM yaitu ketersediaan sarana dan prasaanan serta pengetahuan petugas mengenai SPM.

Studi pendahuluan yang dilakukan peneliti menemukan bahwa ketersediaan sarana dan prasarana di RSUD Kabupaten Klungkung sudah sesuia dengan standar untuk rumah sakit tipe B. Hasil wawancara yang dilakukan peneliti kepada sekretaris Penjamin Mutu Kepuasan Pasien (PMKP) di RSUD Kabupaten Klungkung, pada tahun 2010 pernah dilakukan sosialisasi mengenai SPM sebelum diterapkan SPM di RSUD Kabupaten Klungkung tetapi tidak 
seluruh petugas RSUD Kabupaten Klungkung yang mengikuti sosialisasi tersebut melainkan hanya kepala bagian/bidang, kepala ruangan dan kepala instalasi yang mengikuti sosialisasi tersebut. Saat mulai diterapkan SPM RSUD Kabupaten Klungkung yaitu pada tahun 2012 hingga saat ini tidak pernah lagi dilakukan sosialisasi khusus terkait dengan SPM RSUD Kabupaten Klungkung melainkan hanya dengan memberikan panduan tertulis mengenai SPM RSUD Kabupaten Klungkung. Informasi mengenai SPM biasanya diberikan pada saat rapat yang dilakukan oleh PMKP, hal tersebut mengakibatkan tidak meratanya informasi bagi seluruh petugas. Beberapa orang petugas yang berkerja pada instalasi gawat darurat, instalasi farmasi, dan instalasi laboratorium diwawancarai menyatakan bahwa mereka tidak pernah mendapatkan sosialisasi mengenai SPM bahkan mereka tidak mengetahui detail mengenai indikator yang ada dalam SPM.

\section{METODE}

Penelitian ini merupakan penelitian deskriptif kuantitatif dengan pendekatan cross-sectional. Penelitian ini dilaksanakan di RSUD Kabupaten Klungkung. Pengambilan data dengan pengisian kuesioner. Populasi pada penelitian ini adalah seluruh petugas pelaksana pada instalasi gawat darurat dan penunjang pelayanan kegawatdaruratan RSUD Kabupaten Klungkung. yaitu, sebanyak 94 orang. Teknik pengambilan sampel dalam penelitian ini adalah total sampling, se hingga besar sampel dalam penelitian ini adalah seluruh petugas pelaksana pada instalasi gawat darurat dan penunjang pelayanan kegawatdaruratan RSUD Kabupaten sebanyak 94 orang.

HASIL

Tabel 1 Distribusi Tingkat Pengetahuan Responden Tentang SPM

\begin{tabular}{ccc}
\hline Pengetahuan & Frekuensi (orang) & Proporsi (\%) \\
\hline Baik & 81 & $86,17 \%$ \\
Kurang Baik & 13 & $13,83 \%$ \\
& & \\
\hline Total & 94 & $100 \%$ \\
\hline
\end{tabular}

Berdasarkan tabel 1 diatas, sebagian besar responden memiliki tingkat pengetahuan baik yaitu sebesar $86,17 \%$.

Tabel 2 Tingkat Pengetahuan Responden berdasarkan Karakteristik
Sedangkan responden dengan tingkat pengetahuan kurang baik sebesar 13,83\%.

\begin{tabular}{|c|c|c|c|}
\hline \multirow{3}{*}{ Variabel } & \multicolumn{2}{|c|}{ Pengetahuan } & \multirow{3}{*}{ Total } \\
\hline & Baik & Kurang Baik & \\
\hline & $f(\%)$ & f ( $(\%)$ & \\
\hline
\end{tabular}




\begin{tabular}{|c|c|c|c|}
\hline \multicolumn{4}{|l|}{ Umur } \\
\hline 18-24 & $6(85,71 \%)$ & $1(14,29 \%)$ & $7(100 \%)$ \\
\hline $25-29$ & $23(82,14 \%)$ & $5(17,86 \%)$ & $28(100 \%)$ \\
\hline$\geq 30$ & $52(88,14 \%)$ & $7(11,86 \%)$ & $59(100 \%)$ \\
\hline \multicolumn{4}{|l|}{ Jenis } \\
\hline Kelamin & $51(96,23 \%)$ & $2(3,77 \%)$ & $53(100 \%)$ \\
\hline Perempua & $30(73,17 \%)$ & $11(26,8 \%)$ & $41(100 \%)$ \\
\hline \multicolumn{4}{|l|}{$\mathrm{n}$} \\
\hline \multicolumn{4}{|l|}{ Laki-laki } \\
\hline \multicolumn{4}{|l|}{ Masa Kerja } \\
\hline $0-4$ & $25(86,21 \%)$ & $4(13,79 \%)$ & $29(100 \%)$ \\
\hline $5-10$ & $33(84,62 \%)$ & $6(15,38 \%)$ & $39(100 \%)$ \\
\hline$>10$ & $23(88,46 \%)$ & $3(11,54 \%)$ & $26(100 \%)$ \\
\hline \multicolumn{4}{|l|}{ Pendidikan } \\
\hline SMA & $14(87,50 \%)$ & $2(12,50 \%)$ & $16(100 \%)$ \\
\hline DIII & $51(87,93 \%)$ & $7(12,07 \%)$ & $58(100 \%)$ \\
\hline S1 & $16(80,00 \%)$ & $4(20,00 \%)$ & $20(100 \%)$ \\
\hline \multicolumn{4}{|l|}{ Unit Kerja } \\
\hline IGD & $18(69,2 \%)$ & $8(30,8 \%)$ & $26(100 \%)$ \\
\hline Radiologi & $9(75 \%)$ & $3(25 \%)$ & $12(100 \%)$ \\
\hline Farmasi & $10(100 \%)$ & 0 & $10(100 \%)$ \\
\hline Laboratoriu & $11(100 \%)$ & 0 & $11(100 \%)$ \\
\hline $\mathrm{m}$ & $23(100 \%)$ & 0 & $23(100 \%)$ \\
\hline PONEK & $10(83,3 \%)$ & $2(16,7 \%)$ & $12(100 \%)$ \\
\hline Ambulance & & & \\
\hline
\end{tabular}

Berdasarkan tabel 2 diatas, Responden berumur $\geq 30$ tahun sebagian besar memiliki tingkat pengetahuan baik, yaitu sebesar $88,14 \%$,sedangkan yang memiliki tingkat pengetahuan kurang baik sebesar 11,86\%. Sebagian besar responden yang berjenis kelamin perempuan memiliki tingkat pengetahuan baik yaitu sebesar $96,23 \%$ dan yang memiliki tingkat pengetahuan kurang baik sebesar 3,77\%.

Responden berjenis kelamin laki-laki yang memiliki tingkat pengetahuan baik sebesar $73,17 \%$ dan yang memiliki tingkat pengetahuan kurang baik sebesar $26,83 \%$.
Sebagian besar responden dengan masa kerja $>10$ tahun yang memiliki tingkat pengetahuan baik, yaitu sebesar 88,46\% sedangkan dengan tingkat pengetahuan kurang baik sebesar $11,54 \%$. Responden dengan pendidikan DIII memiliki tingkat pengetahuan baik paling tinggi dari jenjang pendidikan lainnya, yaitu sebesar $87,93 \%$ dan tingkat pengetahuan kurang baik sebesar $12,07 \%$. Seluruh responden yang berkerja di instalasi farmasi (DEPO IGD), Laboratorium, dan PONEK memiliki tingkat pengetahuan dengan kategori baik 


\section{DISKUSI}

Tingkat pengetahuan responden di RSUD Kabupaten Klungkung tentang SPM, sebagian besar responden memiliki tingkat pengetahuan baik. Hal tersebut terjadi karna keberadaan SPM di RSUD Kabupaten Klungkung sudah sejak tanggal 1 Januari 2012, sehingga sebagian besar petugas yang memahami tentang pelayanan minimal yang harus dilakukan dalam memberikan pelayanan. Namun masih terdapat responden yang memiliki tingkat pengetahuan kurang baik tentang SPM, sedangkan SPM merupakan standar minimal yang harus diketahui dan diterapkan oleh petugas di setiap unit untuk mingkatkan mutu pelayanan rumah sakit. Sebagian besar responden kurang memahami mengenai standar minimal yang harus dicapai pada setiap indikator yang terdapat pada SPM sesuai dengan standar nasional. Hasil penelitian ini sejalan dengan hasil penelitian yang dilakukan oleh Heru Setyawan (2015), yang menunjukkan bahwa pengetahuan petugas sebagian besar dengan kategori baik mengenai waktu tanggap pelayanan kegawatdaruratan yang merupakan salah satu indikator dalam SPM.

Hasil penelitian menunjukkan sebagian besar responden yang dalam penelitian ini adalah petugas yang berumur $\geq 30$ yaitu $62,77 \%$. Tingkat pengetahuan responden berdasarkan umur menujukkan bahwa sebagian besar tingkat pengetahuan dengan kategori baik pada responden umur $\geq 30$. Hal tersebut memperlihatkan bahwa semakin bertambahnya usia petugas maka akan bertambah juga pengetahuan yang dimiliki. Bertambahnya umur seseorang akan menimbulkan perubahan baik secara fisik maupun psikologi. Perubahan pada aspek psikologi yaitu seseorang akan semakin matang cara berfikirnya dan hal tersebut akan berpengaruh dalam menerima atau memahami suatu informasi. Selain itu, seseorang yang memiliki umur lebih tua akan memiliki pengalaman lebih banyak dibandingkan yang memiliki umur lebih muda, baik pengalaman pribadi maupun pengalaman orang di lingkungannya. Sejalan dengan Singgih (1998) yang menjelaskan bahwa semakin tua usia seseorang maka proses perkembangan mentalnya bertambah baik. Penelitian sebelumnya yang dilakukan Ayu Darmawati dan Nyoman Wirata (2005) menjelaskan bahwa saat semakin cukup umur tingkat kematangan dan kekuatan seseorang akan lebih matang dalam berfikir dan bekerja, begitu juga dengan pengetahuan yang dimiliki akan semakin meningkat melalui pengalamannya sendiri, pengelaman orang lain dan lingkungannya.

Responden yang memiliki jenis kelamin perempuan memiliki tingkat pengetahuan dengan kategori baik lebih tinggi dibandingkan dengan responden dengan jenis kelamin laki-laki. Hal tersebut karena perempuan lebih bersedia untuk menambah pengetahuannya dari pada laki-laki. Selain itu, perempuan lebih terampil dan detail dalam melakukan sesuatu sehingga perempuan akan mencari lebih banyak informasi guna menambah pengetahuannya terhadap sesuatu. Hasil penelitian ini sejalan dengan Syachori (2012) yang menyatakan 
bahwa perempuan lebih mudah untuk menerima suatu informasi guna mambah pengetahuannya. Hal tersebut juga ditunjukkan pada hasil penelitian Aziz dan Mangestuti (2005) yang menjelaskan bahwa dalam hal tingkat kecerdasan intelektual perempuan memiliki kemampuan yang lebih baik daripada laki-laki.

Responden dengan masa kerja $>10$ memiliki tingkat pengetahuan dengan kategori baik dengan frekuensi tertinggi. Hal tersebut menunjukkan bahwa semakin lama masa kerja maka pengetahuan yang dimiliki juga semakin meningkat. Tingkat kematangan dalam berpikir dan berperilaku juga dipengaruhi oleh pengalaman kehidupan, hal ini menunjukkan bahwa semakin lama masa kerja akan semakin meningkat pengetahuan yang dimiliki. Seperti yang dijelaskan oleh Notoatmodjo (2007) bahwa masa kerja yang lama akan cenderung membuat seorang merasa lebih nyaman pada suatu organisasi, hal ini disebabkan karena telah beradaptasi terhadap lingkungannya yang cukup lama sehingga seorang pegawai merasa sudah nyaman dengan lingukungan tersebut.

Berdasarkan hasil penelitian ini, menunjukkan bahwa sebagian besar jenjang pendidikan DIII memiliki tingkat pengetahuan dengan kategori baik. Menurut Undang-undang Republik Indonesia Nomor 12 Tahun 2012 tentang Pendidikan Tinggi, menjelaskan bahwa pendidikan DIII merupakan bagian dari pendidikan tinggi. Pendidikan seseorang akan mempengaruhi pengetahuan yang dimiliki, hal tersebut terjadi karena semakin tinggi pendidikannya maka akan semakin mudah menerima dan memahami suatu informas. Selain itu, semakin tinggi pendidikan maka informasi yang dimiliki semakin banyak, baik terkait bidangnya maupun diluar bidangnya. Pada hasil penelitian ini, pengetahuan baik pada responden DIII lebih tinggi daripada reponden S1, hal tesebut terjadi karena tenaga vokasional (jenjang DIII) lebih sering memberikan pelayanan langsung, sehingga dari pelayanan yang sering dilakukan maka akan menambah pemahamannya mengenai standar pelayanan minimal.

Tingkat Pengetahuan berdasarkan unit kerja menunjukkan bahwa pengetahuan terhadap SPM pada setiap unit kerjanya, seluruh responden memiliki tingkat pengetahuan baik pada instalasi farmasi, laboratorium dan PONEK. Sedangkan pada instalasi gawat darurat, radiologi, dan unit ambulancen, masih terdapat responden yang memiliki tingkat pengetahuan kurang baik mengenai SPM. Hal tersebut terjadi karena responden kurang memperhatikan standar minimal setiap indikator yang ada dalam SPM, seperti yang terlihat dalam indikator pengetahuan responden, bahwa lebih banyak responden kurang memahi mengenai standar minimal dari setiap indikator.

\section{SIMPULAN}

Berdasarkan hasil penelitian dan pembahasan dapat penulis simpulkan sebagai berikut :

1. Tingkat pengetahuan petugas di IGD dan penunjang pelayanan 
kegawatdaruratan RSUD Kabupaten Klungkung tentang SPM, sebagian besar dengan kategori baik yaitu sebesar $86,17 \%$.

2. Tingkat pengetahuan petugas berdasarkan karakteristik dengan kategori baik sebagian besar pada umur $\geq 30$ tahun, jenis kelamin perempuan, pendidikan DIII dan masa kerja $>10$ tahun.

\section{SARAN}

Adapun saran yang bisa penulis berikan sebagai berikut :

1. RSUD Kabupaten Klungkung sebaiknya mengadakan sosialisasi yang merata bagi seluruh petugas di Instalasi Gawat Darurat dan penunjang pelayanan kegawatdaruratan utamanya di instalasi gawat darurat, radiologi, dan unit ambulance secara rutin dan terjadwal, sehingga informasi yang dimiliki oleh setiap petugas merata.

2. Setiap unit kerja mengadakan pertemuan rutin staf setiap bulan untuk mengevaluasi pencapaian target dalam SPM di masing-masing unit atau instalasi, sehingga dapat menyusun langkah-langkah perbaikan demi peningkatan mutu pelayanan.

3. Penelitian selanjutnya dapat mengembangkan penelitian dengan meneliti di bagian atau instalasi lainnya dengan metode yang berbeda agar mendapatkan informasi lebih mendalam mengenai pengetahuan tentang SPM. Selain itu peneliti selanjutnya dapat mengembangkan penelitian dengan mencari faktor lain penyebab tidak tercapainya indikator dalam SPM.

\section{DAFTAR PUSTAKA}

Depkes RI. (2009). Sistem Kesehatan Nasional. Jakarta.

Gunarsa, Singgih D. Dasar dan Teori Perkembangan Anak. Jakarta: Gunung Mulia

Hidayat, A.A. (2007). Metode Penelitian Kebidanan Dan Teknik Analisis Data. Surabaya: Salemba

Ismail dkk. (2013). Pengetahuan Perawat Tentang Kegawatan Nafas Dan Tindakan Resusutasi Jantung Paru Pada Pasien Yang Mengalami Kegawatan Pernafasan Di Ruang ICU Dan UGD RSUD Kolonodale Propinsi Sulawesi Tengah. Makassar: STIKES Nani Hasanuddin Makassar. Vol. 3 No.4 Desember 2013.

Kementrian Kesehatan Republik Indonesia. (2008) Keputusan Menteri Kesehatan Republik Indonesia Nomor: 129/Menkes/SK/II/2008 Tentang Standar Pelayanan Minimal Rumah Saki.

Notoatmodjo,S. (2012). Metodologi Penelitian Kesehatan. Jakarta : Rineka Cipta.

Nurhasim dkk. (2015). Pengetahuan Perawat Tentang Response Time Dalam Penanganan Gawat Darurat Di Ruang Triage RSUD Karanganyar. Jawa Tengah: STIKES Kusuma Husada Surakarta 
Arc. Com. Health Juni 2019

ISSN: 2527-3620

Robbins, S.P. (2006). Perilaku Organisasi. Edisi Kesepuluh. Jakarta: PT Indeks Kelompok Gramedia.

Riyadi. Sugeng. (2007).Keperawatan Kesehatan Masyarakat. Jakarta: Salemba Medika 